\title{
Paleometeorology: visualizing mid-latitude dynamics at the synoptic level during the Last Glacial Maximum
}

M. B. Unterman ${ }^{1}$, T. J. Crowley ${ }^{1}$, K. I. Hodges ${ }^{2}$, S. J. Kim ${ }^{3}$, and D. J. Erickson ${ }^{4}$

${ }^{1}$ Grant Institute, School of Geosciences, University of Edinburgh, Edinburgh, UK

${ }^{2}$ Environmental Systems Science Centre, University of Reading, Reading, UK

${ }^{3}$ Korea Polar Research Institute KORDI, Incheon, Korea

${ }^{4}$ Center for Computational Sciences, Oak Ridge National Labs, Tennessee, USA

Received: 29 May 2009 - Accepted: 24 June 2009 - Published: 14 July 2009

Correspondence to: M. B. Unterman (m.b.unterman@sms.ed.ac.uk)

Published by Copernicus Publications on behalf of the European Geosciences Union.

Paleometeorology: visualizing mid-latitude dynamics

M. B. Unterman et al.

\section{Title Page}

Abstract

Conclusions

Tables

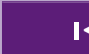

14

4

Back

Full Screen / Esc

Printer-friendly Version

Interactive Discussion 


\section{Abstract}

High resolution animations of the ice age surface have been developed as a tool for in-depth analysis of "paleometeorological" features. Synoptic-scale weather conditions of the Last Glacial Maximum (LGM) are simulated using the National Center for Atmo5 spheric Research (NCAR) Community Climate Model version 3 (CCM3.6) on a globally resolved T170 $(\sim 75 \mathrm{~km})$ grid domain. Model outputs have been saved at hourly intervals in order to better resolve diurnal features. The simulation has been run in tandem with a lower temporally resolved simulation of Kim et al. (2008) to enable a first-pass assessment of significance of features in the shorter run. Both simulations were forced 10 with modified CLIMAP sea ice and sea surface temperatures (SSTs), reduced global $\mathrm{CO}_{2}$, ice sheet topography, lower sea level, and $21000 \mathrm{BP}$ orbital parameters. Results from the North Pacific show continued high storm activity during the LGM, whereas the North Atlantic tends to be more quiescent. Plots of storm tracks indicate that all North Pacific storms were steered northward into the Gulf of Alaska, bringing relatively warm 15 air and precipitation into the region. This result is consistent with increased poleward heat transport into the region in the LGM climatological run as well as the absence of evidence for glaciation in middle Alaska. Storm-track trajectories should also have decreased upwelling along the northwest American coast - a response consistent with some geological data. The storms and other atmospheric features are illustrated in a high-resolution animation, which may also be useful as a teaching tool. Further investigation of these runs may provide additional insight into features such as wave-wave interactions, which have previously been unavailable to the research community for an alternate-Earth climate that has been at least as common as the present one over the last 500000 years.
5, 1883-1899, 2009

\section{Paleometeorology: visualizing mid-latitude dynamics}

M. B. Unterman et al.

Title Page

Abstract Introduction

Conclusions

Tables

References

Figures

14

$>1$

4

Back

Close

Full Screen / Esc

Printer-friendly Version

Interactive Discussion 


\section{Introduction}

Recent high spatially-resolved model studies of the LGM have advanced our understanding of Earth's climatic response to massive northern-hemispheric ice sheets (e.g. Toracinta et al., 2004; Kim et al., 2008). Studies are now better able to quantify 5 mesoscale processes such as temperature and precipitation changes over ice sheets and regions of moderate topography (Bromwich et al., 2004; Toracinta et al., 2004; Kim et al., 2008). Models such as the Community Climate Model version 3.6 (CCM3.6) can be run at grid resolutions higher than $1^{\circ}$ (latitude/longitude), resolving geographical and topographical features more efficiently than ever before. This suggests that the scientific community is approaching a modelling environment capable of global synoptic scale or "paleometeorological" analyses.

Although earlier model studies have lent considerable insight into the understanding of ice-age climate dynamics (e.g. Gates, 1976; Kutzbach and Wright, 1985; Kutzback and Gueter, 1986; Kageyama et al., 1999), it would be impractical to attempt a "meteorological" simulation at those resolutions. For a "paleometeorological" analysis the spatial resolution needs to be sufficient to accurately represent both topography and synoptic-scale processes. A practical, but by no means trivial corollary, involves the necessity of data-storage capabilities large enough to handle the high temporal and spatial resolution outputs.

Here we report on an exploratory investigation of LGM model weather on the hourly scale, using a high resolution global climate model to assess synoptic scale differences between the North Pacific and North Atlantic during one model winter of the Earth's last great ice age, and the potential usefulness of saving and analyzing data at this scale. From a climatological viewpoint, this test would seem very limited. However, from the meteorological perspective, the time scale of our useful "data" is comparable to those obtained from large-scale field experiments such as GATE or TOGA-COARE, observations of which have been of considerable value not only to the meteorological but also the climate communities (e.g. Shin et al., 1990; Webster and Lucas, 1992).
5, 1883-1899, 2009

\section{Paleometeorology: visualizing mid-latitude dynamics}

M. B. Unterman et al.

Title Page

Abstract Introduction

Conclusions

Tables

References

Figures

14

$>$ I

4

Back

Close

Printer-friendly Version

Interactive Discussion 


\section{Methods}

We utilize the Community Climate Model version 3.6 (CCM3.6) physics, coupled with a Land Surface Model (LSM) version 1.1, stored at the Department of Energy's (DOE) Center for Computational Science (CCS) at Oak Ridge National Labs (ORNL). Model 5 outputs were saved at every hour for both an LGM and modern (control) run. Each simulation incorporated the CCM3.6's T170 resolution, where a $\sim 75 \mathrm{~km}$ grid interval was spread over a global domain. A total of 68 variables on 18 sigma levels were saved at hourly steps. Hourly saves were deemed useful to better understand and portray features related to diurnal heating (which over land south of the Laurentide lce 10 Sheet in North America is quite substantial) and potential future analyses focusing on wave-wave interactions.

Boundary conditions for the winter LGM run consisted of prescribed sea surface temperatures (SST) derived from CLIMAP (1981), except that temperatures have been uniformly lowered by $1^{\circ} \mathrm{C}$ to be more consistent with recent analyses (Crowley, 2000;

15 Ballantyne et al., 2005). The LGM CO 2 concentration was set to $200 \mathrm{ppm}$ consistent with data from the Vostok ice core (Petit et al., 1999). Sea level was dropped $120 \mathrm{~m}$ and LGM ice sheet topography was taken from the Peltier (1994) ICE-4G reconstruction (the newer estimate of ICE-5G (Peltier, 2004) was not available at the start of the climatological simulation). Modified CLIMAP sea ice patterns were taken from the climatological simulation of Kim et al. (2008). The winter sea ice limit was specified near $42^{\circ} \mathrm{N}$ consistent with faunal assemblage counts and sedimentological criteria outlined by McIntyre et al. (1976). This is considered an extreme limit, useful for testing the limits of model response; future investigations can be done to test the sensitivity of the main results to uncertainties in this field (e.g. MARGO, 2009)

25 Control SST's are derived from Shea et al. (1990). The LGM December, January, February (DJF) run was initialized on the first day of the model month of December; frequent re-submissions had to be done manually due to limits on data storage. Approximately two thousand hours of model output were obtained with the first $500 \mathrm{~h}$ dis-
$5,1883-1899,2009$

\section{Paleometeorology: visualizing mid-latitude dynamics}

M. B. Unterman et al.

Title Page

Abstract Introduction

Conclusions

Tables

References

Figures

14

$\Delta$

4

Back

Close

Full Screen / Esc

Printer-friendly Version

Interactive Discussion 
carded as spin-up. The total amount of data, both output and post-processed, exceeds 40 terabytes for both sets of simulations and their associated control runs.

Animations comprised of frames from hourly saves were rendered from a custom built software package built to handle the large data sets and to accurately compile 5 high resolution, 256 color images from high resolution outputs. We felt that pre-built packages, such as the Grid Analysis and Display System (GrADS), would not accurately portray certain climatological parameters and surface features at the T170 level as they are generally limited in their colour profile.

Sea level pressure (SLP) and vorticity-based storm tracking was done to validate 10 animation observations, using the methodology of Hoskins and Hodges (2002). Tracking was done for the entire northern hemisphere and then predefined regions were analyzed separately for tracks within the region.

\section{Results}

The four-year annual composite of DJF SLP was first compared to the ERA40 re15 analysis data (T159 resolution) to determine if the climatological control (modern) run was comparable to observations. Given the offset in baseline years for the two runs, the position of the Aleutian and Icelandic lows and subtropical highs are certainly "reasonable" (Fig. 1). The eastward displacement of the Azores high is expected for this version of the CCM, when compared to re-analysis data (Hurrell et al. 1998).

20 Comparing synoptic and climatological simulations is also necessary to see if the short, simulated winter of the former is representative. The synoptic simulation is compared to the LGM multi-year climatology in Fig. 1. The high and low pressure regions in the Pacific are comparable. However, in the climatological run the northeast Atlantic contains a well defined low pressure core, which is absent in the synoptic simulation (or 25 displaced far to the west). To address this discrepancy we examined inter-annual SLP variability seen within the LGM climatological simulation (Fig. 2). Based on the scatter plot of extremes and inter-annual SLP for these years (Fig. 3), the short synoptic run is

$5,1883-1899,2009$

\section{Paleometeorology: visualizing mid-latitude dynamics}

M. B. Unterman et al.

Title Page

Abstract Introduction

Conclusions References

Tables Figures

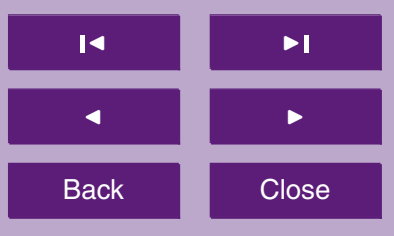

Full Screen / Esc

Printer-friendly Version

Interactive Discussion 
(statistically) within the range of mean values for the LGM climatological run - for the Icelandic Low, mean, and two sigma range of variability is $995 \pm 13.4 \mathrm{hPa}$, as compared to $1005 \mathrm{hPa}$ in the synoptic run.

The high resolution animations (cf. Animation) enable a better appreciation of the 5 features that are responsible for the changes in the mean climate state (Fig. 1). The Pacific is characterized by strong fronts generated from the outflow of air off eastern Siberia. Many of these fronts traverse the length of the North Pacific, forming large cyclonic systems bound for the western coast of North America. All of these storms are then steered northward over Alaska delivering warmer air and convective precipitation 10 to the region above $57^{\circ} \mathrm{N}$ (Figs. 6, 7). This is coincident with the region of increased mean annual poleward heat transport from Kim et al. (2008) and a proposed white spruce (Picea glauca) refugium in the sector (Anderson et al., 2006). It is also the region where no ice formed during the LGM - a very unusual circumstance for such a high-latitude region. Hourly storm tracking supports these animation observations 15 (Fig. 4).

Other meteorological features in the animations which we have not yet examined in detail include shear zones between two high pressure regions east of Hawaii (hour 976) and North Pacific serial-storms (hours 743-849).

In the North Atlantic, storms are constrained along the southern edge of the sea ice 20 margin and rarely migrate northward of $43^{\circ} \mathrm{N}-44^{\circ} \mathrm{N}$ due to the lack of a latent heat source. Tracking of large storms (Fig. 4) highlights the difference between the North Atlantic and North Pacific. There are nine large magnitude storms in the Pacific and only one in the North Atlantic within the same category.

Storm counts in the North Atlantic (Fig. 5) reveal a broad standard distribution in 25 vorticity intensity during the modern, with the major peaks ranging from 3.5 to 9.5 (1/sec). The LGM however is skewed to less intense storms within the same window. The North Pacific is the opposite story, with LGM storms shifted towards a slightly higher intensity with the major peaks around 3.5 to $7.5(1 / \mathrm{sec})$. Very large storms are also identified in the North Pacific LGM simulation with several storms reaching the 14.5

\section{Paleometeorology: visualizing mid-latitude dynamics}

M. B. Unterman et al.

Title Page

Abstract Introduction

Conclusions References

Tables Figures

14

4

Back

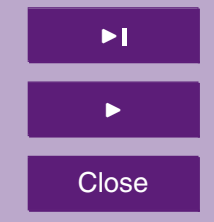

Full Screen / Esc

Printer-friendly Version

Interactive Discussion 
and even $16.5(1 / \mathrm{sec})$ levels. The intensity distribution between the LGM North Atlantic and North Pacific is consistent with the interpretation of storm magnitude changes seen in the animation.

\section{Discussion and conclusions}

5 One of the main results from this pilot study is that there has been a decrease in the amount of North Atlantic cyclogenesis in the LGM. This result is supported in both our climatological run and other current works (e.g. Li and Battisti, 2008). A new regional result supplied by our study involves the changes in North Pacific trajectories, with all storms steered into the Gulf of Alaska. This persistent response is presumably a 10 consequence of the semi-permanent upper level high over the enormous Laurentide Ice Sheet. The advection of warmth into this region can help explain the nearly ice-free conditions in interior Alaska in the LGM, and the large wave-number one distortion of the upper level flow leads to a compensatory enhanced northward flow in the North Atlantic sector, thereby helping to explain the very large LGM temperature decreases 15 for Greenland (Dahl-Jensen et al., 1998; Kim et al., 2008). Enhanced south-westerly flow offshore of western North America should also have reduced Ekman upwelling along the coast, conceivably leading to warmer temperatures in this region. Alkenone paleotemperature estimates from the California Current support such an interpretation (Herbert et al., 2001).

20 Whereas the changes in North Pacific storm trajectories can be readily understood, the changes in North Atlantic storm frequency might be more open to question concerning robustness of model response. The shift into the central North Atlantic of the LGM jet, presumably due to the expanded sea ice, is consistent with some effect on Atlantic cyclogenesis. Li and Battisti (2008), present evidence suggesting relative 25 robustness of this feature, citing a reduction in Atlantic jet seeding to be the cause. Nevertheless, this suggests the need for further investigation on the synoptic level.

It is important to note that the northward steering of low pressure systems is probably 1889
5, 1883-1899, 2009

\section{Paleometeorology: visualizing mid-latitude dynamics}

M. B. Unterman et al.

Title Page

Abstract Introduction

Conclusions

References

Tables Figures

14

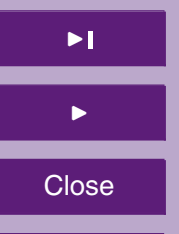

Back

Full Screen / Esc

Printer-friendly Version

Interactive Discussion

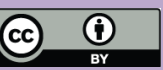


very dependent on height of the North American ice sheet, and that different glaciological reconstructions can sometimes have significantly different heights for that ice sheet. We use the Peltier (1994) G4 reconstruction, which has significantly less ice west of Hudson Bay than the newer, G5 reconstruction (Peltier, 2004). Some caution 5 is therefore needed with respect to our results until we repeat our analyses with the G5 ice sheet - a nontrivial addition amount of work because of the intensive computing requirements for our project. We speculate that the higher ice sheet will not significantly change the result, as we would expect the higher elevation G5 ice sheet would further amplify the stationary ridge-trough system anchored over western North

10 America, and the lower relief G4 ice sheet in our run is already steering all the low pressures northward. The consistency of our Pacific results with ice-free parts of Alaska and a wave-number one perturbation of the highest latitude flow causing cooling over Greenland and Western Europe is consistent with paleo-observations, and also supports our conjecture. Nevertheless, we acknowledge that an actual model run to test 15 the sensitivity of such changes is necessary, and we plan to do that in the future.

Despite the above caveats, selected use of high-resolution models, even in the synoptic mode, may help investigators better understand some key features and processes of ice-age circulation. Our future work will focus on examining some features of the system response over central North America, south of the ice sheet, and in the Drake 20 Passage, where preliminary analysis of the model output suggests additional insights be obtained from synoptic-scale investigations. The movies used to highlight some of our results may be useful for teaching and future research studies, and are available to all interested parties.

http://www.clim-past-discuss.net/5/1883/2009/cpd-5-1883-2009-supplement.zip

25 Acknowledgements. We thank the Center for Computational Science (CCS) team at ORNL for making this work possible. We thank the British Atmospheric Data Centre (BADC) for access to ERA40 data sets. We also thank Simon Tett, David Sugden, Dick Kroon, Bob Harwood, Katie Noake, Rich Taylor and Hillary Jenkins for their discussions and Stephen Obrochta for technical assistance. This study was supported by ORNL and the University of Edinburgh

\section{Paleometeorology: visualizing mid-latitude dynamics}

M. B. Unterman et al.

Title Page

Abstract Introduction

Conclusions References

Tables Figures

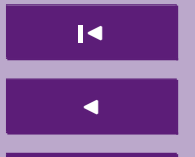

$>$ I

Back

Close

Full Screen / Esc

Printer-friendly Version

Interactive Discussion 
School of Geosciences. Seong-Joong Kim was supported by the project "Paleoclimate Modelling Study for Polar Regions (PE08140)" of the Korea Polar Research Institute.

\section{References}

Anderson, L. L., Sheng Hu, F., Nelson, D. M., Petit, R. J., and Paige, K. N.: Ice-age endurance:

5 DNA evidence of a white sprice refugium in Alaska, PNAS, 103, 33, 12447-12450, 2006.

Ballantyne, A. P., Lavine, M., Crowley, T. J., Liu, J., and Baker P. B.: Meta-analysis of tropical surface temperatures during the last glacial maximum, J. Geophys. Res. Lett., 32, L05712, doi:10.1029/2004GL021217, 2005.

Betts, A. K. and Ridgway, W.: Tropical boundary layer equilibrium in the last ice age, J. Geophys.

10 Res. Lett., 97, 2529-2534, 1992.

Boville B. A. and Gent, P. R.: The NCAR climate system model, version 1, J. Climate, 11, 1115-1130, 1998.

Bromwich, D. H., Toracinta, E. R., Wei, H., Oglesby, R. J., Fastook, J. L., and Hughes, T. J.: Polar MM5 Simulations of the Winter Climate of the Laurentide Ice Sheet at the LGM, J.

15 Climate, 17, 3415-3433, 2004.

CLIMAP: The surface of the Ice Age Earth. Science, 191, 1131-1136, 1976.

CLIMAP: Seasonal reconstructions of the Earth's surface at the last glacial maximum. Geol. Soc. Amer. Map Chart Ser., MC36, 1981.

Collins, W. D.: The community climate system model version 3 (CCSM3), J. Climate, 19, 21222143, 2006a.

Crowley, T. J.: CLIMAP SSTs revisited, Clim. Dyn., 16, 241-255, 2000.

Dahl-Jensen, D., Mosegaard, K., Clow, G. D., Johnsen, S. J., Hansen, A. W., Balling, N.: Past Temperatures Directly from the Greenland Ice Sheet, Science, 282, 268-271, 1998.

Gates, W. L.: The numerical simulation of ice-age climate with a global general circulation model, J. Atmos. Sci., 33, 1844-1876, 1976.

Herbert, T. D., Schuffert, J. D., Andreasen D., et al.: Collapse of the California Current during glacial maxima linked to climate change on land, Science, 293, 71-76, 2001.

Hoskins, B. J. and Hodges, K. I.: New perspectives on the northern hemisphere winter storm tracks, J. Atmos. Sci., 59, 1041-1061, 2002.

Paleometeorology: visualizing mid-latitude dynamics

M. B. Unterman et al.

Title Page

Abstract Introduction

Conclusions

References

Tables

Figures

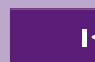

14

$\rightarrow$

4

Back

Close

Full Screen / Esc

Printer-friendly Version

Interactive Discussion 
Hurrell, J. W., Hack, J. J., Boville, B. A., Williamson, D. L., Kiehl, J. T.: The dynamical simulation of the NCAR Community Climate Model Version 3 (CCM3), J. Climate, 11, 1207-1236, 1998.

Kageyama, M., Valdes, P. J., Ramstein, G., Hewitt, C., and Wyputta, U.: Northern hemisphere storm tracks in present day and last glacial maximum climate simulations: A comparison of the European PMIP models, J. Climate, 12, 742-760, 1999.

Kim, S., Crowley, T. J., Erickson, D. J., Govindasamy, B., Duffy, P. B., and Lee, B. Y.: Highresolution climate simulation of the last glacial maximum, Clim. Dyn., 31, 1-16, 2008.

Kutzbach, J. E. and Guetter, P. E.: The influence of changing orbital parameters and surface boundary conditions on climate simulations for the past 18000 years, J. Atmos. Sci., 16, $10 \quad 1726-1759,1986$.

Kutzbach, J. E. and Wright Jr., H. E.: Simulation of the climate of 18000 yr BP: Results for the North American/North Atlantic/European Sector, Quat. Sci. Rev., 4, 147-187, 1985.

$\mathrm{Li}, \mathrm{C}$. and Battisti, D. S.: Reduced Atlantic storminess during the Last Glacial Maximum: Evidence from a coupled climate model, J. Climate, 21, 3561-79, 2008.

15 MARGO Project Members: Constraints on the magnitude and patterns of ocean cooling at the Last Glacial Maximum, Nature Geo., 2, 127-132, 2009.

Peltier, W. R.: Ice Age paleotopography, Science, 265, 195-201, 1994.

Peltier, W. R.: Global glacial isostasy and the surface of the ice-age earth: The ICE-5G (Vm2) model and GRACE, Annu. Rev. Earth Planet. Sci., 32, 111-49, 2004.

20 Peltier, W. R. and Solheim, L. P.: The climate of the Earth at last glacial maximum: statistical equilibrium state and a mode of internal variabilityl, Quat. Sci. Rev., 23, 335-357, 2004.

Shea, D. J., Trenberth, K. E., and Reynolds, R. W.: A global monthly sea surface temperature climatology, NCAR Tech. Note NCAR/TN-345+STR, 167 pp., 1990.

Shin, K. S., North,G. R. Ahn, Y. S., and Arkin, P. A.: Time scales and variability of area-averaged tropical oceanic rainfall, Mon. Wea. Rev., 118, 1507-1516, 1990.

Toracinta, E. R., Oglesby, R. J., and Bromwich, D. H.: Atmospheric response to modified CLIMAP ocean boundary conditions during the Last Glacial Maximum, J. Climate, 17, 504522, 2004.

Unterman, M. B.: High resolution simulations of synoptic scale meteorology for the last glacial maximum, Duke University Archives, M.S., U61H, 2007.

Webster, P. J. and R. Lukas: TOGA COARE: The coupled ocean-atmosphere response experiment. Bull. Amer. Meteor. Soc, 73,1377-1416, 1992.

Paleometeorology: visualizing mid-latitude dynamics

M. B. Unterman et al.

Title Page

Abstract Introduction

Conclusions References

Tables Figures

14

4

Back

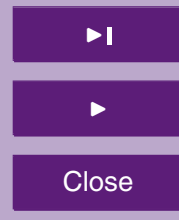

Full Screen / Esc

Printer-friendly Version

Interactive Discussion 

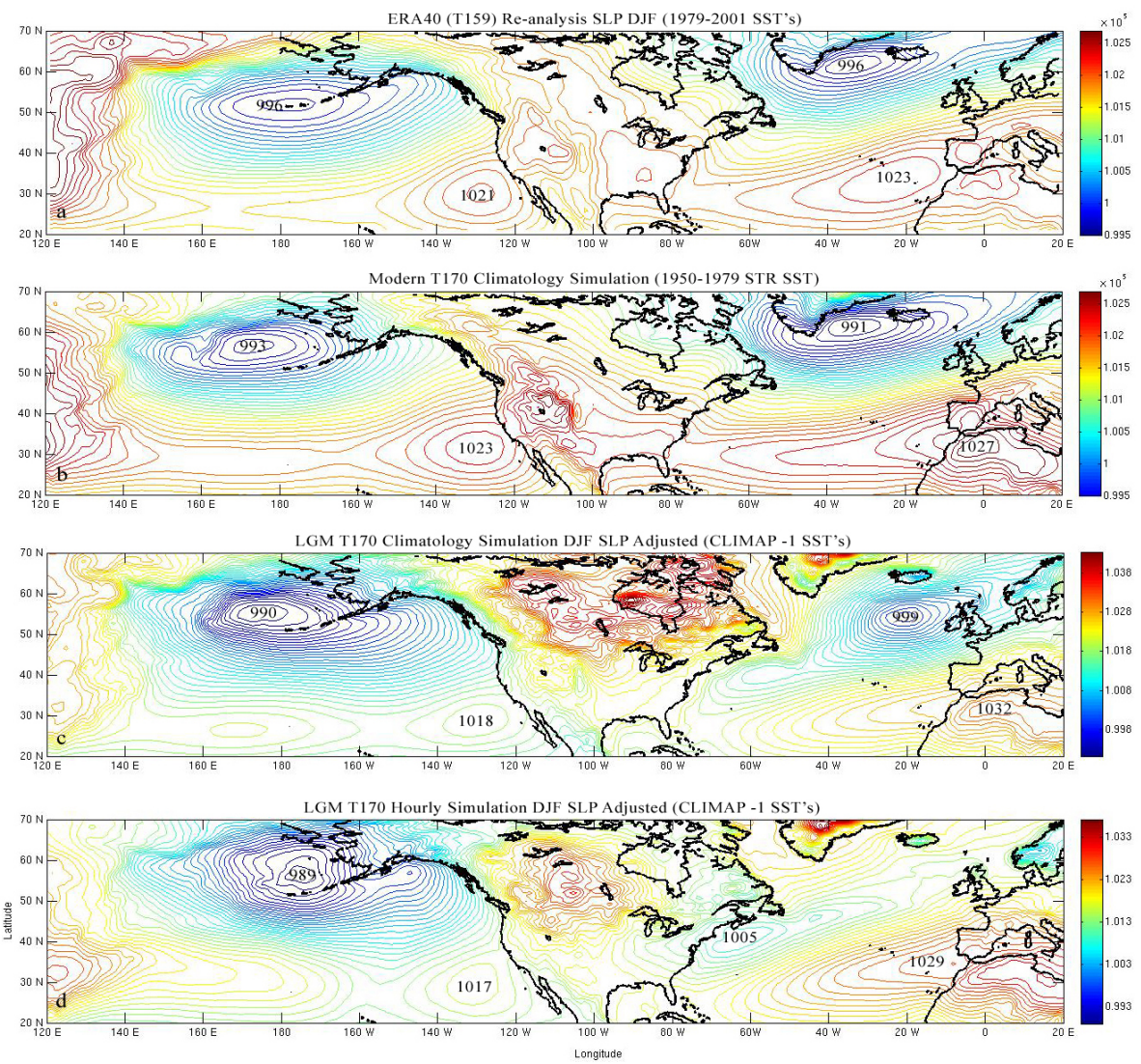

Fig. 1. ERA40 SLP data obtained from the British Atmospheric Data Centre (topmost) is compared to the multi-year climatological simulation of Kim et al. (2008) and the two different temporal resolution simulations of the LGM. To aid in comparison with the present, LGM SLP has been decreased by $12 \mathrm{mb}$ to be roughly consistant with a lowering of $120 \mathrm{~m}$ in sea level (Betts and Ridgway, 1992).

Paleometeorology: visualizing mid-latitude dynamics

M. B. Unterman et al.

\section{Title Page}

Abstract

Conclusions

Tables

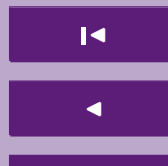

Back

\section{Introduction}

References

Figures

$\rightarrow 1$

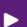

Close

\section{Full Screen / Esc}

Printer-friendly Version

Interactive Discussion 

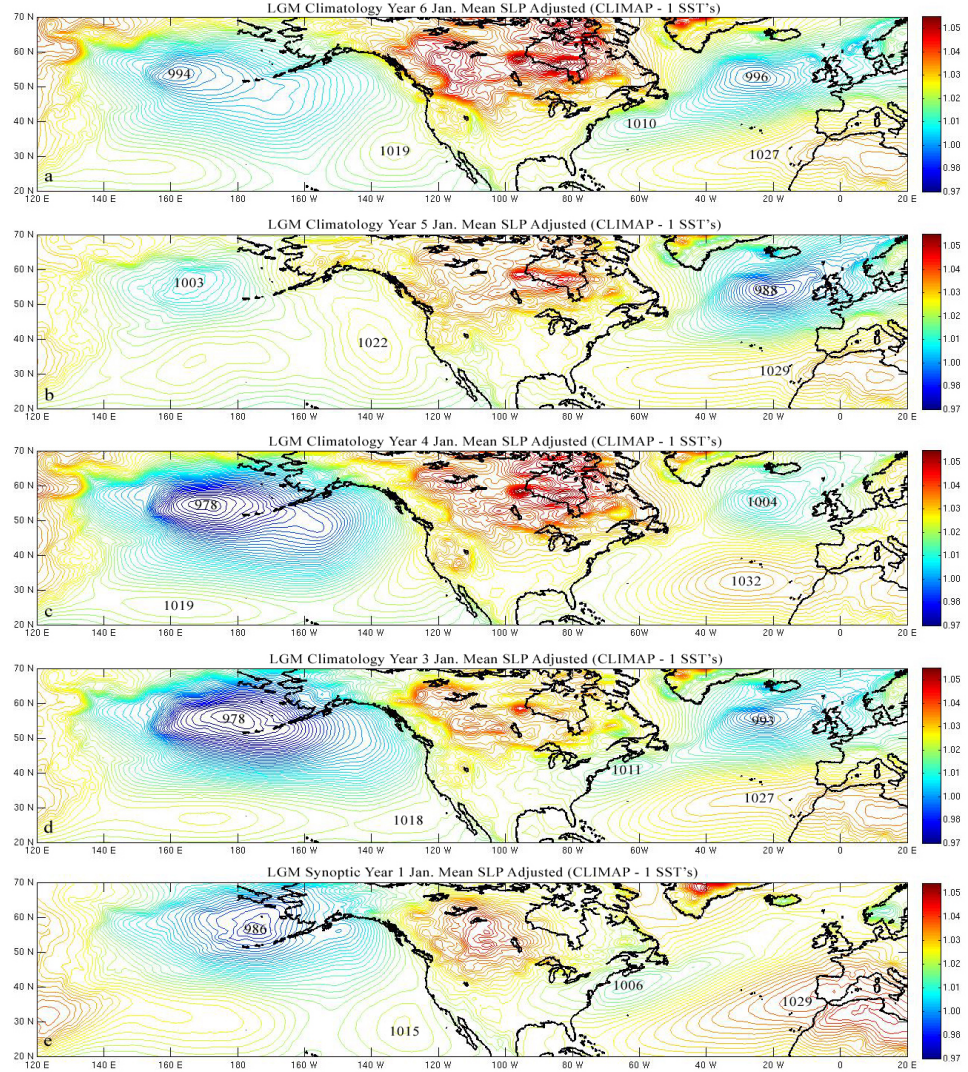

Fig. 2. LGM January mean SLP between the four consecutive years after spin up in the climatological simulation and the hourly simulation's January month. To aid in comparison with the present, LGM SLP has been decreased by $12 \mathrm{mb}$ to be roughly consistant with a lowering of $120 \mathrm{~m}$ in sea level (Betts and Ridgway, 1992).

5, 1883-1899, 2009

\section{Paleometeorology:}

$$
\begin{gathered}
\text { visualizing } \\
\text { mid-latitude } \\
\text { dynamics }
\end{gathered}
$$

M. B. Unterman et al.

\section{Title Page}

\section{Abstract}

Conclusions

Tables

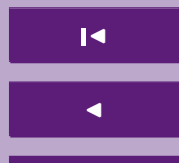

Back

\section{Full Screen / Esc}

Printer-friendly Version

Interactive Discussion 


\section{$5,1883-1899,2009$}

LGM Synoptic Pressure Differences vs.

"Climatology"

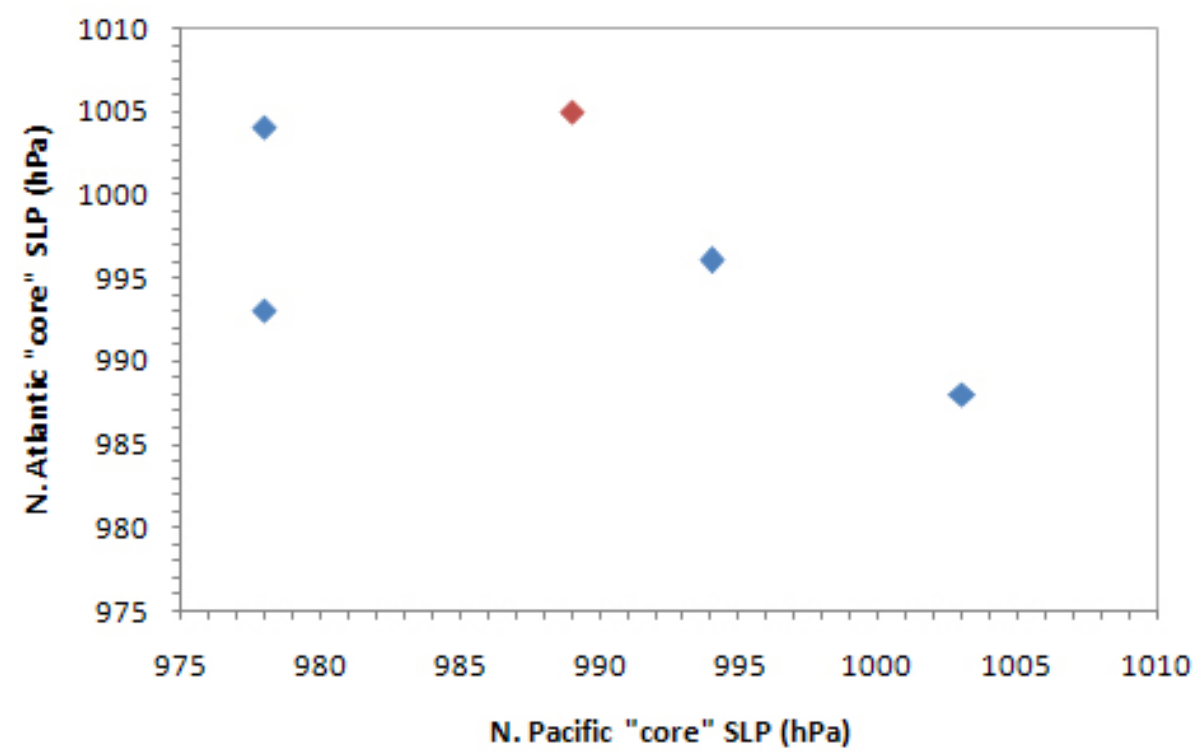

Fig. 3. Comparison of inter-annual SLP variability in the climatological run (in this case all model months of January) compared to the mean SLP of the synoptic simulation.

\section{Paleometeorology: visualizing mid-latitude dynamics}

M. B. Unterman et al.

\section{Title Page}

Abstract

Introduction

Conclusions

References

Tables Figures

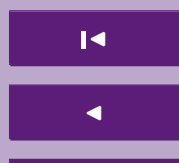

Back

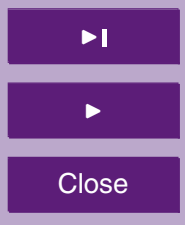

Full Screen / Esc

Printer-friendly Version

Interactive Discussion 


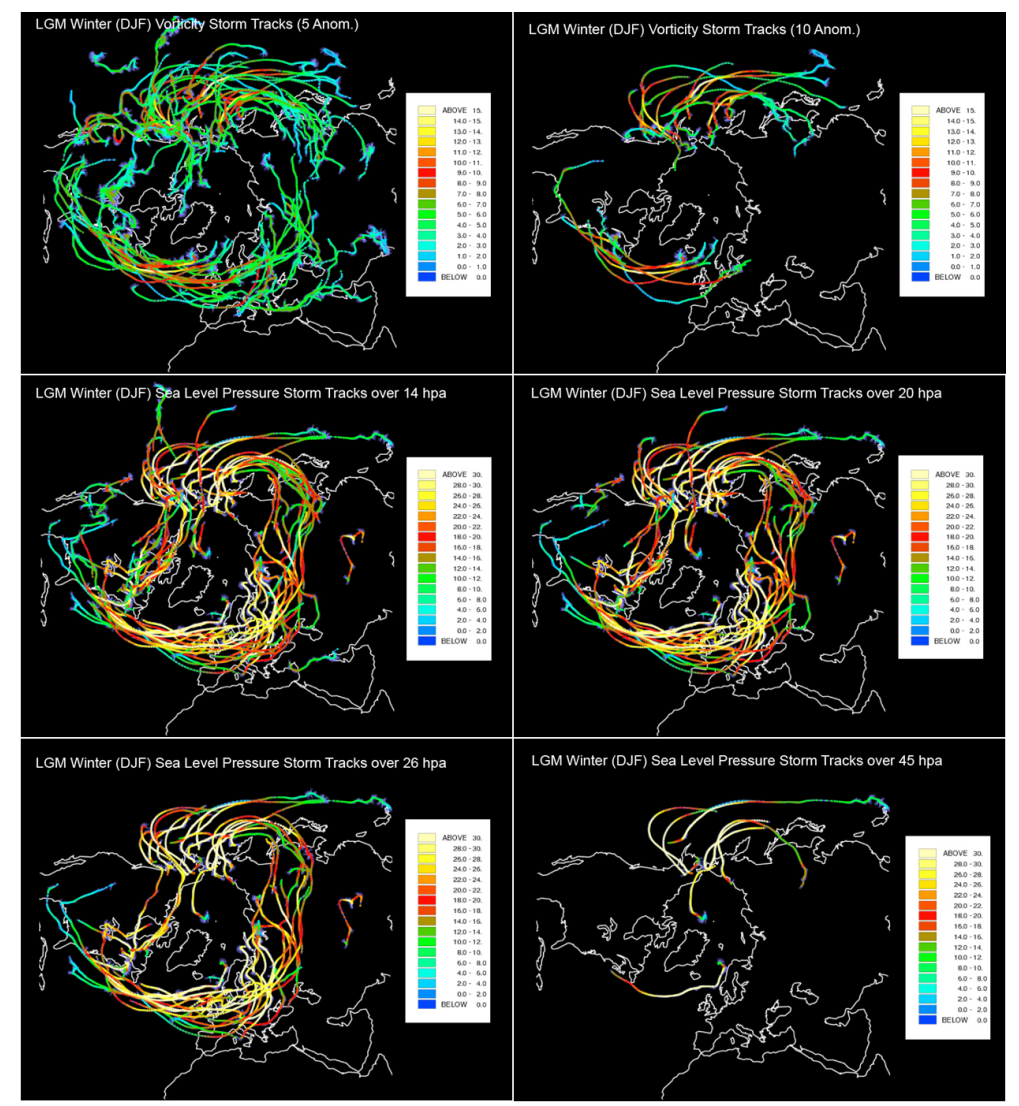

Fig. 4. LGM storm tracks using vorticity and mean SLP variations with the same methods as Hoskins and Hodges (2002).

\section{$5,1883-1899,2009$}

Paleometeorology: visualizing mid-latitude dynamics

M. B. Unterman et al.

Title Page

Abstract

Conclusions

Tables

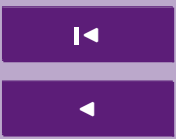

Back

Full Screen / Esc

Printer-friendly Version

Interactive Discussion 


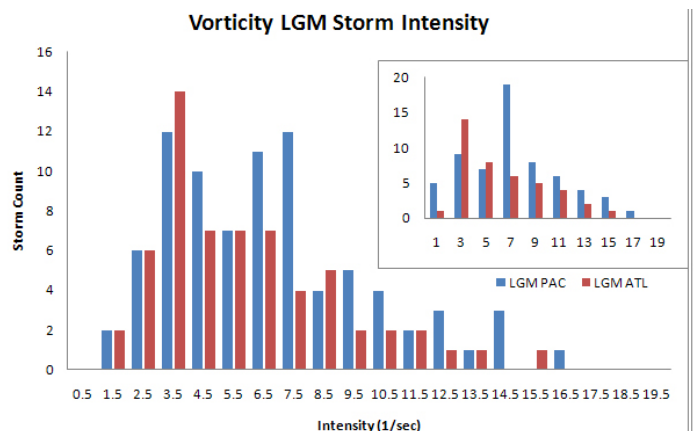
Intensity $(1 / \mathrm{sec})$

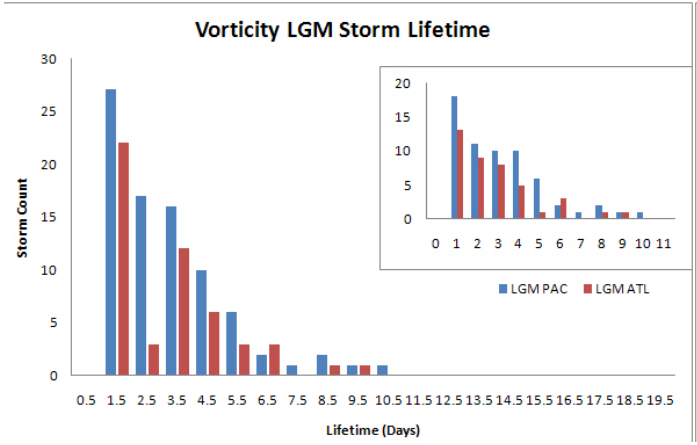

Lifetime (Days)

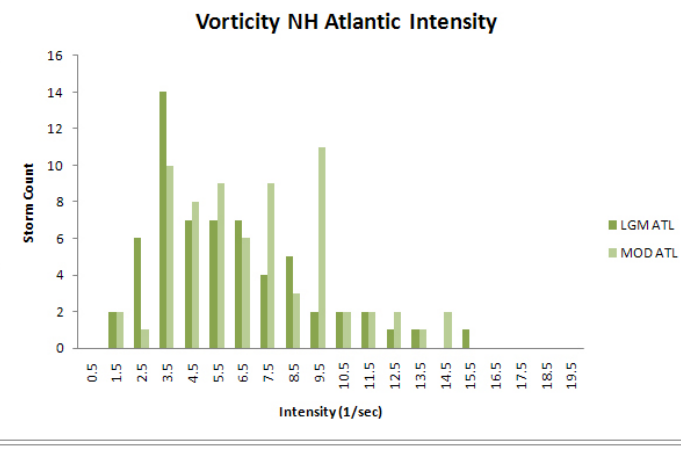

Vorticity NH Pacific Intensity

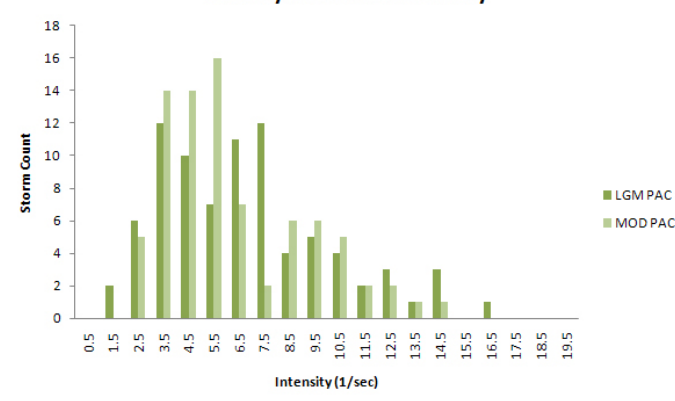

Fig. 5. (Top left) LGM winter storm intensity between the North Pacific $\left(140^{\circ}, 230^{\circ}\right),\left(25^{\circ}, 70^{\circ}\right)$ and North Atlantic $\left(290^{\circ}, 360^{\circ}\right),\left(25^{\circ}, 70^{\circ}\right)$ where storms were counted upon entering the region but their maximum could occur anywhere along the storm track. Insets demonstrate those storms that only achieve their maximum intensity within the predefined window. LGM winter storm lifetime between the North Pacific and North Atlantic sectors using the same method as the intensity calculation (Bottom Left). Right most panels are North Atlantic (Top right) and North Pacific (Bottom right) storm intensities between the LGM and control run simulations. Note the phase shift between the two basins.

$5,1883-1899,2009$

Paleometeorology: visualizing mid-latitude dynamics

M. B. Unterman et al.

Title Page

\section{Abstract}

Conclusions

Tables

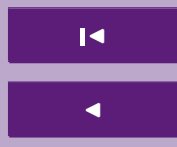

Back

\section{Introduction}

References

Figures

$>\mathbf{I}$

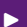

Close

\section{Full Screen / Esc}

Printer-friendly Version

Interactive Discussion 

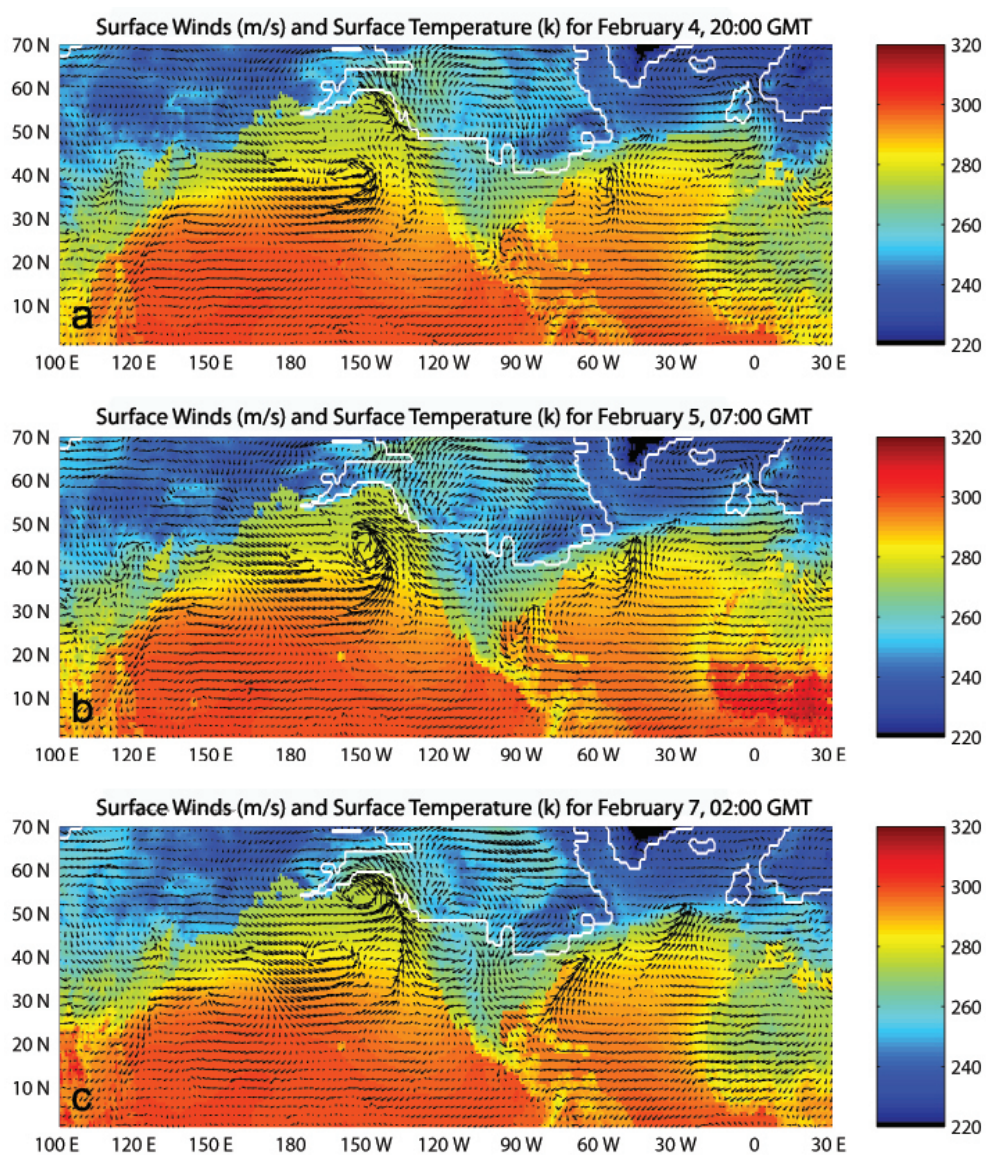

Fig. 6. Monitoring a trans-Pacific storm that formed off the north east coast of Siberia and was eventually deflected northward along the enhanced ridging towards middle Alaska. It should be noted that this is a relatively large storm with winds exceeding the $45-50 \mathrm{~m} / \mathrm{s}$ mark after 5 February, 07:00 GMT model time.
$5,1883-1899,2009$

Paleometeorology: visualizing mid-latitude dynamics

M. B. Unterman et al.

Title Page

\section{Abstract}

Conclusions

Tables

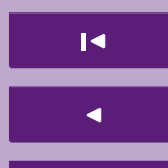

Back

\section{Introduction}

References

Figures

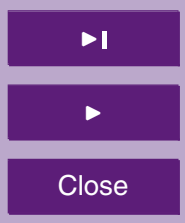

Full Screen / Esc

Printer-friendly Version

Interactive Discussion 


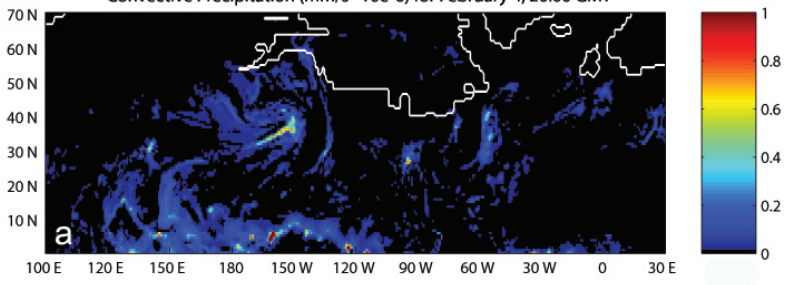

Convective Precipitation $(\mathrm{mm} / \mathrm{s} * 10 \mathrm{e}-6)$ for February 5, 07:00 GMT
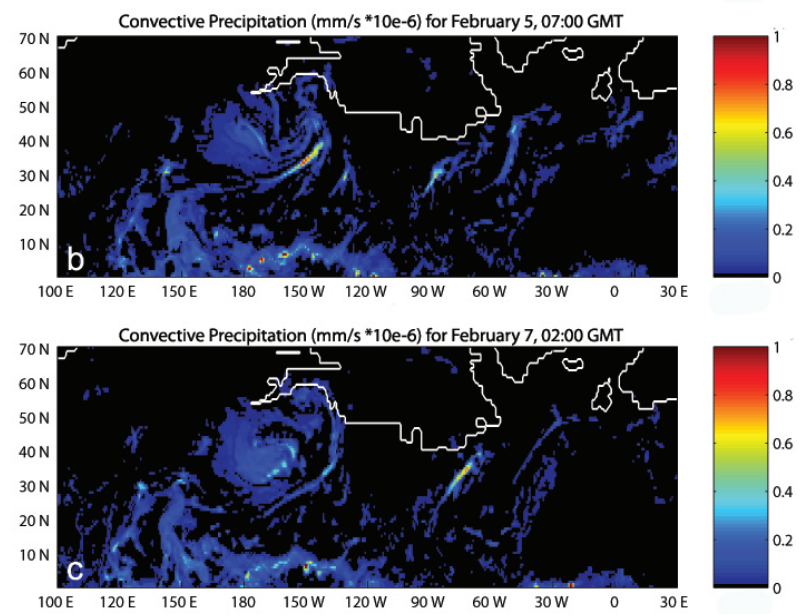

Fig. 7. Tracking the same large Pacific storm shown in the surface wind fields of figure \#5 but within the Convective Precipitation parameter. White outline is the margin of the ice sheet. Pacific storms such as this one, which formed off the north east coast of Siberia or northern Japan, bring relatively warmer air to middle Alaska as well as the potential for strong rain or serial rain-out events. Serial storms have been tracked in the animations where a large, trailing parent front causes successive multiple secondary storms to deflect into the mid-Alaska region.

5, 1883-1899, 2009

Paleometeorology: visualizing mid-latitude dynamics

M. B. Unterman et al.

\section{Title Page}

Abstract

Conclusions

Tables

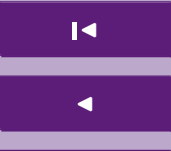

Back

Full Screen / Esc

Printer-friendly Version

Interactive Discussion 